\title{
Association of Hepatitis C Virus With Alcohol Use Among U.S. Adults
}

NHANES 2003-2010

Amber L. Taylor, MPH, ${ }^{1}$ Maxine Denniston, $\mathrm{MSPH},{ }^{1}$ R. Monina Klevens, DDS, MPH, ${ }^{1}$ Lela R. McKnight-Eily, $\mathrm{PhD},{ }^{2}$ Ruth B. Jiles, $\mathrm{PhD}, \mathrm{MS}, \mathrm{MPH}^{1}$

From the ${ }^{1}$ Division of Viral Hepatitis, NCHHSTP, CDC, Atlanta, Georgia; and ${ }^{2}$ Division of Population Health, CDC, Atlanta, Georgia

Address correspondence to: Amber L. Taylor, MPH, Division of Viral Hepatitis, NCHHSTP, CDC, 1600 Clifton Road, MS G-37, Atlanta GA 30329. E-mail: altaylor1@cdc.gov. 
Introduction: Excessive alcohol use exacerbates morbidity and mortality among hepatitis C virus (HCV)-infected people. The purpose of this study was to describe self-reported patterns of alcohol use and examine the association with HCV infection and other sociodemographic and health-related factors.

Methods: Data from 20,042 participants in the 2003-2010 National Health and Nutrition Examination Survey were analyzed in 2014. Estimates were derived for self-reported demographic characteristics, HCV-RNA (indicative of current HCV infection) status, and alcohol use at four levels: lifetime abstainers, former drinkers, non-excessive current drinkers, and excessive current drinkers.

Results: Former drinkers and excessive current drinkers had a higher prevalence of HCV infection $(2.2 \%$ and $1.5 \%$, respectively) than never or current non-excessive drinkers $(0.4 \%$ and $0.9 \%$, respectively). $\mathrm{HCV}$-infected adults were estimated to ever drink five or more drinks/day almost every day at some time during their lifetime about 3.3 times more often $(43.8 \%$ vs $13.7 \%$, $p<0.001)$ than those who were never HCV infected. Controlling for age, sex, race/ethnicity, education, and having a usual source of health care, HCV infection was significantly associated with excessive current drinking (adjusted prevalence ratio, $1.3 ; 95 \% \mathrm{CI}=1.1,1.6$ ) and former drinking (adjusted prevalence ratio, $1.3 ; 95 \% \mathrm{CI}=1.1,1.6$ ).

Conclusions: Chronic HCV infection is associated with both former and excessive current drinking. Public health HCV strategies should implement interventions with emphasis on alcohol abuse, which negatively impacts disease progression for $\mathrm{HCV}$-infected individuals. 


\section{Introduction}

Excessive alcohol consumption causes an estimated 88,000 deaths/year and $\$ 223.5$ billion in economic costs in the U.S. ${ }^{1}$ It has caused 2.5 million years of potential life lost each year in the U.S. from 2006 to 2010. Among those who died, excessive alcohol use shortened lives by an average of 30 years. $^{2}$ There are an estimated 2.7 million people chronically infected with hepatitis $\mathrm{C}$ virus (HCV) and HCV infection is associated with 17,000 deaths in the U.S. each year. ${ }^{3,4}$ However, owing to under-reporting of HCV deaths, it has been suggested that at least 80,000 HCV-infected people may have died in $2010 .{ }^{5}$ Complications associated with chronic HCV infection include cirrhosis and hepatocellular carcinoma, which are projected to increase substantially within the next decade, and are leading causes for liver transplantation. ${ }^{6-10}$ Alcohol use has been identified as a primary predictor in the progression of those complications. ${ }^{11}$ Excessive alcohol use among individuals chronically infected with HCV was associated with an increased risk of all-cause and liver-related mortality compared with infected people without excessive alcohol use. ${ }^{12}$ In 2010, alcohol-related liver disease ranked third as a cause of death among people with hepatitis $\mathrm{C} .^{4}$

Highlighting the comorbidity of HCV infection and alcohol abuse, CDC's and the U.S. Preventive Services Task Force's recommendations for HCV testing of people born during 1945-1965 explicitly included screening for alcohol use among HCV antibody-positive individuals. ${ }^{13}$ Although alcohol use is a known factor in the progression of liver disease, there are few studies that have assessed the association between chronic HCV infection and patterns of alcohol use among U.S. adults using nationally representative data. Other studies have identified a significantly higher prevalence of $\mathrm{HCV}$ in liver cancer patients with alcoholic cirrhosis. ${ }^{14} \mathrm{~A}$ 
study examining patient reports of drinking among people with chronic HCV found that almost two thirds reported drinking more than once a week at diagnosis. ${ }^{15}$ The purpose of this study was to describe self-reported patterns of alcohol use and examine the association with HCV infection and other sociodemographic and health-related factors.

\section{Methods}

\section{Design Overview}

The National Health and Nutrition Examination Survey (NHANES), conducted by CDC's National Center for Health Statistics, collects nationally representative data on the health and nutritional status of the U.S. non-institutionalized civilian population. This survey uses a complex probability sampling design and collects information from approximately 5,000 people

of all ages annually using standardized interviews, physical examinations, and tests of biological samples. Participants were interviewed in their homes to ascertain demographic characteristics and in the Mobile Examination Center to ascertain possible risks and exposures for HCV infection. People aged $\geq 16$ years and emancipated minors were interviewed directly. All participants provided written informed consent. More details on survey design, including approval from the National Center for Health Statistics IRB, are available from documentation at www.cdc.gov/nchs/nhanes/nhanes_questionnaires.htm.

\section{Measures}

Main outcome was pattern of alcohol use. Analyses were restricted to participants aged $\geq 20$ years because public use files do not include alcohol data on those aged $<20$ years. Responses to questions on amount and frequency of alcohol consumption were used to create four mutually exclusive levels of alcohol use, adapted from the classification by Tsai et al. ${ }^{16}$ Lifetime 
abstainers reported $<12$ drinks ever. Former drinkers reported $\geq 12$ drinks in their lifetime but none in the past year. Non-excessive current drinkers, on average, reported $\leq 14$ drinks/week for men or on average, seven or fewer drinks/week for women, and never five or more drinks/day in a single day during the past year for either. Excessive current drinkers, on average, reported $>14$ drinks/week for men or on average more than seven drinks/week for women, or five or more drinks/day in a single day at least once during the past year for either. HCV-RNA status was determined from laboratory testing of participant blood specimens. Specimens were tested by CDC's Division of Viral Hepatitis Laboratory, first for HCV antibody (anti-HCV) using a qualitative screening test. Repeatedly reactive specimens were then tested using a confirmatory recombinant immunoblot assay. Samples with positive or indeterminate assay results were tested for HCV-RNA. Details on laboratory testing are at www.cdc.gov/nchs/nhanes/nhanes20092010/lab_methods_09_10.htm. Participants were classified as chronically HCV infected if their recombinant immunoblot assay test for anti-HCV was positive or indeterminate and their test for $\mathrm{HCV}-\mathrm{RNA}$ was positive and as never $\mathrm{HCV}$ infected if they were anti-HCV negative. Those who were anti-HCV positive or indeterminate but RNA-negative (resolved infections) were not included in the analysis because of the small size of this group $(n=90)$.

Several HCV- and alcohol-relevant factors were evaluated, including access to care (have a usual source of medical care) and having health insurance. Other independent categorical variables included in analyses were age, sex, race/ethnicity, poverty status, and education level. The poverty index ratio (www.census.gov/hhes/www/poverty/poverty.html) was categorized for analysis into below poverty $(<1.0)$, near poverty $(1.0-1.9)$, or above poverty $(\geq 2.0)$.

\section{Statistical Analysis}


The authors used SUDAAN, version 10.0, a statistical package designed to analyze complex survey data, for all analyses except testing related to collinearity evaluation, which was performed using SAS, version 9.3. Estimates were weighted to represent the total U.S. noninstitutionalized civilian population and to account for oversampling and nonresponse to the household interview and physical examination. Weights were further adjusted to account for the fact that not all examination participants were tested for anti-HCV, not all participants who tested positive or indeterminate for anti-HCV have serum available for HCV RNA testing, and multiple years of data were being used. Statistical analyses were performed in 2014.

Demographic (age at interview, sex, race/ethnicity, education, and poverty index ratio) and other (HCV status, having a usual source of medical care and health insurance coverage) characteristics were estimated and compared for each pattern of alcohol use. Chi-square tests were used for comparisons. Prevalence ratios were obtained for two outcomes (excessive versus non-excessive current drinking and former versus current drinking) using simple and multivariate logistic regression models. Simple models contained only the outcome and a single covariate. Multivariate models were constructed using backwards elimination, with age, sex, and race/ethnicity plus variables that were significant in the simple logistic models for each outcome included in the initial multivariate model. The final multivariate models contained only significant variables plus age, sex, and race/ethnicity. When the final multivariate models were evaluated for collinearity, HCV infection was collinear with all other cofactors as judged by a condition index $>30.0$. This problem did not occur when similar analyses were previously performed using only two 2-year cycles (2005-2008) of NHANES. Therefore, the collinearity test was suspected to be oversensitive given the increased sample size resulting from using four 
rather than two cycles of NHANES. Spearman correlations were calculated between the independent variables in each final model as an alternative method to judge collinearity. A $p$ value of $<0.05$ was considered statistically significant and used to determine which covariates to retain during multivariate modelling.

\section{Results}

Of the 30,114 people aged $\geq 20$ years sampled for NHANES 2003-2010, 22,173 (73.6\%) were interviewed and 21,281 (96.0\% of those interviewed) were examined. Serum samples were available for anti-HCV testing for 20,042 (94.2\%) of examined participants. Of the 456 who were anti-HCV positive $(n=381)$ or indeterminate $(n=75), 395(86.6 \%)$ had additional serum available for HCV RNA testing; 271 were RNA-positive (estimated RNA prevalence, 1.3\%; 95\% CI-1.1, 1.5). Of the 271 currently HCV-infected participants, 244 provided sufficient information on alcohol consumption for inclusion in the analysis.

Estimated population characteristics by self-reported alcohol use are shown in Table 1. Most U.S. adults were current drinkers, most frequently non-excessive (41.7\%) drinkers. An estimated 17.2\% were former drinkers and $11.3 \%$ were lifetime abstainers. Statistically significant differences were found for all characteristics investigated across the four categories of alcohol use. Current excessive drinkers were younger whereas former drinkers or lifetime abstainers were older. Lifetime abstainers, former drinkers, and current non-excessive drinkers were more frequently female than male and current excessive drinkers were more frequently male than female. Differences were observed across patterns of alcohol consumption within all race/ethnicity groups. Excessive current drinkers had the lowest frequency of having a usual 
source of medical care or having health insurance. Current drinkers most frequently had income at or above poverty level and more than a high school education.

Former and excessive current drinkers had a higher estimated prevalence of HCV infection. Specifically, adults with chronic infection were estimated to be former drinkers about 1.7 times more often $(31.0 \%, 95 \% \mathrm{CI}=25.1,37.6)$ than those never infected with $\mathrm{HCV}(17.0 \%, 95 \%$ $\mathrm{CI}=15.7,18.3, p<0.001)$. Among current drinkers, HCV-infected adults were estimated to be excessive current drinkers about 1.3 times more often $(54.9 \%, 95 \% \mathrm{CI}=43.2,66.0)$ compared with those not infected $(41.4 \%, 95 \% \mathrm{CI}=40.0,42.8, p<0.05)$. In addition, those with chronic infection were estimated to have consumed five or more drinks/day every day or almost every day at some time(s) during their life $(43.8 \%, 95 \% \mathrm{CI}=36.3,51.6)$ about 3.3 times more often than those not infected $(13.7 \%, 95 \% \mathrm{CI}=13.0,14.5, p<0.001)$. Based on these differences, two separate outcomes were investigated: excessive versus non-excessive current drinking and former versus current drinking.

In simple logistic models, excessive current drinking was significantly more likely among those who were HCV-infected, younger, male, with no usual source of medical care or no health insurance, with no education above high school, and with income below twice the poverty level. Furthermore, excessive current drinking was significantly less likely among non-Hispanic blacks (Table 2). In the final multivariate model, HCV infection was still significantly associated with excessive current drinking; only health insurance and poverty did not retain significant associations (Table 2). When testing for collinearity, removing the variable for HCV resulted in all condition indices being <30.0. Spearman correlations between the six independent variables 
in the final model ranged from 0.01064 to 0.21731 ; only three were $>0.1(0.14309,0.14940$, and 0.21731 ) and all correlations with the HCV status variable were $<0.1$.

Estimated characteristics of former and current (both non-excessive and excessive) drinkers are shown in Table 3. Former drinking was significantly more likely among those who were HCVinfected, older, female, of non-Hispanic black race/ethnicity, and with high school education or less. Additionally, former drinking was significantly more likely among those having a usual source of medical care or health insurance and an income less than twice the poverty level. In simple logistic models, being a former rather than a current drinker was significantly more likely among those who were $\mathrm{HCV}$-infected, of non-Hispanic black race/ethnicity, and with high school education or less or income less than twice poverty level, and significantly less likely among those who were younger, male, and who had no health insurance or usual source of medical care (Table 4). In the final multivariate model, only health insurance coverage did not remain statistically associated with being a former drinker (Table 4). When testing for collinearity, only removing the variable for HCV status resulted in all condition indices being $<30.0$. Spearman correlations between the seven independent variables in the final model ranged from 0.00289 to 0.37306 ; six were $>0.1(0.10747,0.11034,0.13663,0.15224,0.23306$, and $0.373106)$ and all correlations with the HCV status variable were $<0.1$.

Because Spearman correlations did not indicate high levels of correlation between independent variables in either of the final multivariate models, models presented in Tables 2 and 4 were believed to be statistically valid and not subject to problems with collinearity. 


\section{Discussion}

Patterns of alcohol use were estimated in a representative sample of the general U.S. population aged $\geq 20$ years. The study examined whether selected sociodemographic and health-related factors, including HCV infection, were associated with alcohol drinking patterns. Former drinkers and excessive current drinkers had the highest prevalence of HCV infection. Controlling for other factors, HCV infection remained significantly associated with both excessive current drinking and former drinking. Former drinkers were significantly more likely to be non-Hispanic black, with chronic HCV infection, high school education or less, and income less than twice the poverty level. Additionally, former drinkers were significantly less likely among those of younger age, male sex, and with no usual source of medical care. Excessive current drinkers were significantly more likely among those of younger age, male sex, high school education or less, and with no usual source of medical care and significantly less likely among non-Hispanic blacks.

Former drinkers were older with a usual source of medical care or health insurance and perhaps more likely to have had their infection progress to a point where they sought medical care, received an $\mathrm{HCV}$ diagnosis, and were advised to stop drinking. Excessive current drinkers being younger and with perhaps less disease progression and being less likely to have a usual source of medical care or health insurance may have been also less likely to have been diagnosed and advised to stop drinking. Morbidity and mortality among people with chronic HCV infection is exacerbated by excessive alcohol use, which accelerates fibrosis. ${ }^{12,17}$ Those with HCV who are hospitalized for alcohol-related complications have a $24 \%$ longer length of stay and are twice as likely to die during the hospitalization. ${ }^{18}$ Clinical management guidelines for HCV-infected 
individuals include addressing alcohol use before initiating treatment for HCV. ${ }^{19}$ This is important, given that the latest generation of $\mathrm{HCV}$ treatments has expanded viral genetic targets of therapy. When used in combination as all-oral therapies or together with PEGylated interferon and ribavirin, approximately $90 \%$ of treated patients achieved cure after 12-24 weeks of therapy. ${ }^{20}$ However, physicians are less inclined to offer treatments to patients if they have a history of alcohol use despite being abstinent even a year before therapy. ${ }^{21}$ There are challenges to $\mathrm{HCV}$ infection treatment, particularly the lack of infrastructure in prevention strategies and the lack of awareness of effective therapies. ${ }^{22}$ Although abstinence from alcohol is preferred, it may not be realistic or necessary for physicans to expect of $\mathrm{HCV}$-infected people. ${ }^{23}$ One option is to use the 2010 U.S. Dietary Guidelines for all Americans, which recommend that women consume one or fewer drink/day and men consume two or fewer drinks/day. ${ }^{24}$

A follow-up survey of people with positive anti-HCV test results during NHANES 2001-2008 found that $50.3 \%$ were unaware of their $\mathrm{HCV}$ status before being notified of their positive test by NHANES and that lack of health insurance was associated with being unaware of their infection. ${ }^{25}$ Of those who had visited a healthcare professional regarding their first positive antiHCV test and had been told they needed regular medical follow-up, nearly $88 \%$ reported they had been advised to avoid or limit alcoholic beverages. However, their self-reported drinking, on average, one or more drink/day during the past 12 months, did not differ from those who said they had not been told to avoid or limit alcohol (49.1\% vs 50.0\%). ${ }^{25}$ This highlights the need for health professionals to offer comprehensive and effective interventions targeting alcohol use/abuse for $\mathrm{HCV}$-infected individuals. Integrated hepatology care systems that offer access to 
mental health clinicians and patient-aligned care teams would be an ideal setting for such interventions. $^{26}$

Excessive alcohol use is a preventable medical and social problem that may be reduced through behavior modification. To reduce alcohol misuse, the U.S. Preventive Services Task Force recommended alcohol screenings and brief behavioral counseling interventions in primary care settings for adults. ${ }^{27}$ The Task Force found that behavioral counseling could reduce total number of drinks/week, episodes of binge or heavy episodic drinking, and increase adherence to drinking guidelines at 6-12 months of follow-up. There is evidence that brief counseling with follow-up and external support can be effective in controlling alcohol use among people with HCV infection. ${ }^{26}$ Motivational Enhancement Therapy has been found to increase abstinence among chronic HCV patients who currently drink and suffer from alcohol use disorders. ${ }^{26}$

Excessive current drinkers were younger and less likely to have insurance or a usual source of care, suggesting a need for targeted alcohol prevention beyond healthcare settings. The Community Preventive Services Task Force Guide reviewed evidence-based strategies to prevent excessive alcohol consumption, and recommended strategies that include but are not limited to increasing alcohol taxes, regulation of alcohol outlet density, and maintaining limits on days of sale. $^{27}$

\section{Limitations}

There were limitations to this study. NHANES data are generalizable to the non-institutionalized civilian population of the U.S. and exclude the homeless and those living in correctional institutions (among whom injection drug use and HCV infection are higher than in the general 
population) and other group settings (e.g., student dormitories, military recruits). It was estimated that these marginalized groups account for almost 1 million $\mathrm{HCV}$-infected people. ${ }^{28}$ Furthermore, an estimated 50\%-90\% of people who inject drugs have anti-HCV depending on the duration of their use..$^{29,30}$ Injection drug users are stigmatized and often decline to answer questions related to health behaviors or undergo phlebotomy procedures. ${ }^{28}$ If this group were also to be identified in household surveys, there could be an additional increase of more than 1 million Americans identified with $\mathrm{HCV}$ infection. ${ }^{28}$ Possible impact of these exclusions on the association between alcohol use and $\mathrm{HCV}$ infection could not be assessed. Importantly, temporal sequence cannot be determined between HCV infection and drinking patterns using crosssectional data. In addition, alcohol use was self-reported and therefore subject to response and recall bias. Finally, data are not available on average lifetime alcohol consumption or duration of drinking, so these factors could not be evaluated.

\section{Conclusions}

In summary, former and excessive current drinkers had the highest prevalence of chronic $\mathrm{HCV}$ infection. Higher prevalence of HCV infection among excessive current drinkers indicates a need for more-comprehensive approaches to primary, secondary, and tertiary care. People infected with $\mathrm{HCV}$ are often not aware of their infection status, and thus not aware of the medical risks associated with the consumption of alcohol or guidelines to educate them on reducing alcohol intake. The implementation of behavioral screenings to identify at-risk drinking among both $\mathrm{HCV}$-infected and uninfected individuals could prevent alcohol abuse and serve as a platform to educate patients on the associated risks. Targeted strategies should emphasize testing to increase HCV awareness among undiagnosed people and decrease disease progression among the 
infected. Findings suggest that many excessive current drinkers did not have a usual source of medical care and or health insurance. Public health actions against alcohol abuse, therefore, should also be available outside of clinical settings and targeted to both those with and without HCV infection. 


\section{Acknowledgments}

Amber L. Taylor was supported in part by an appointment to the Research Participation Program at CDC administered by the Oak Ridge Institute for Science and Education through an interagency agreement between the U.S. Department of Energy and CDC. 


\section{References}

1. Bouchery EE, Harwood HJ, Sacks JJ, Simon CJ, Brewer RD. Economic costs of excessive alcohol consumption in the U.S., 2006. Am J Prev Med. 2011;41(5):516-524. http://dx.doi.org/10.1016/j.amepre.2011.06.045.

2. Stahre M, Roeber J, Kanny D, Brewer RD, Zhang X. Contribution of excessive alcohol consumption to deaths and years of potential life lost in the United States. Prev Chronic Dis. 2014;11:E109. http://dx.doi.org/10.5888/pcd11.130293.

3. Denniston MM, Jiles RB, Drobeniuc J, et al. Chronic hepatitis C virus infection in the United States, National Health and Nutrition Examination Survey 2003 to 2010. Ann Intern Med. 2014;160(5):293-300. http://dx.doi.org/10.7326/M13-1133.

4. Ly KN, Xing J, Klevens RM, Jiles RB, Holmberg SD. Causes of death and characteristics of decedents with viral hepatitis, United States, 2010. Clin Infect Dis. 2014;58(1):40-49. http://dx.doi.org/10.1093/cid/cit642.

5. Mahajan R, Xing J, Liu SJ, et al. Mortality among persons in care with hepatitis C virus infection: the Chronic Hepatitis Cohort Study (CHeCS), 2006-2010. Clin Infect Dis. 2014;58(8):1055-1061. http://dx.doi.org/10.1093/cid/ciu077.

6. Kanwal F, Hoang T, Kramer JR, et al. Increasing prevalence of HCC and cirrhosis in patients with chronic hepatitis C virus infection. Gastroenterology. 2011;140(4):11821188. http://dx.doi.org/10.1053/j.gastro.2010.12.032.

7. Shaw JJ, Shah SA. Rising incidence and demographics of hepatocellular carcinoma in the USA: what does it mean? Expert Rev Gastroenterol Hepatol. 2011;5(3):365-370. http://dx.doi.org/10.1586/egh.11.20. 
8. McHutchison JG, Bacon BR. Chronic hepatitis C: an age wave of disease burden. Am J Manag Care. 2005;11(10 Suppl):S286-295.

9. Rein DB, Wittenborn JS, Weinbaum CM, Sabin M, Smith BD, Lesesne SB. Forecasting the morbidity and mortality associated with prevalent cases of pre-cirrhotic chronic hepatitis C in the United States. Dig Liver Dis. 2011;43(1):66-72. http://dx.doi.org/10.1016/j.dld.2010.05.006.

10. Freeman RB, Jr., Steffick DE, Guidinger MK, Farmer DG, Berg CL, Merion RM. Liver and intestine transplantation in the United States, 1997-2006. Am J Transplant. 2008;8(4 Pt 2):958-976. http://dx.doi.org/10.1111/j.1600-6143.2008.02174.x.

11. McMahon BJ, Bruden D, Bruce MG, et al. Adverse outcomes in Alaska natives who recovered from or have chronic hepatitis $\mathrm{C}$ infection. Gastroenterology. 2010;138(3):922-931. http://dx.doi.org/10.1053/j.gastro.2009.10.056.

12. Younossi ZM, Zheng L, Stepanova M, Venkatesan C, Mir HM. Moderate, excessive or heavy alcohol consumption: each is significantly associated with increased mortality in patients with chronic hepatitis C. Aliment Pharmacol Ther. 2013;37(7):703-709. http://dx.doi.org/10.1111/apt.12265.

13. Smith BD, Morgan RL, Beckett GA, Falck-Ytter Y, Holtzman D, Ward JW. Hepatitis C virus testing of persons born during 1945-1965: recommendations from the Centers for Disease Control and Prevention. Ann Intern Med. 2012;157(11):817-822. http://dx.doi.org/10.7326/0003-4819-157-9-201211060-00529.

14. Bruix J, Barrera JM, Calvet X, et al. Prevalence of antibodies to hepatitis C virus in Spanish patients with hepatocellular carcinoma and hepatic cirrhosis. Lancet. 1989;2(8670):1004-1006. http://dx.doi.org/10.1016/S0140-6736(89)91015-5. 
15. Stoller EP, Hund AJ, Webster NJ, et al. Alcohol consumption within the context of hepatitis C: a qualitative study of non-problematic drinkers. Alcohol Alcohol. 2006;41(5):546-552. http://dx.doi.org/10.1093/alcalc/ag1055 .

16. Tsai J, Ford ES, Li C, Zhao G. Past and current alcohol consumption patterns and elevations in serum hepatic enzymes among U.S. adults. Addict Behav. 2012;37(1):78-84. http://dx.doi.org/10.1016/j.addbeh.2011.09.002.

17. Poynard T, Bedossa P, Opolon P. Natural history of liver fibrosis progression in patients with chronic hepatitis C. Lancet. 1997;349(9055):825-832. http://dx.doi.org/10.1016/S0140-6736(96)07642-8.

18. Tsui JI, Pletcher MJ, Vittinghoff E, Seal K, Gonzales R. Hepatitis C and hospital outcomes in patients admitted with alcohol-related problems. J Hepatol. 2006;44(2):262266. http://dx.doi.org/10.1016/j.jhep.2005.07.027.

19. Ghany MG, Strader DB, Thomas DL, Seeff LB. Diagnosis, management, and treatment of hepatitis C: an update. Hepatology. 2009;49(4):1335-1374. http://dx.doi.org/10.1002/hep.22759.

20. Ward JW. Hepatitis C virus: the 25-year journey from discovery to cure. Hepatology. 2014;60(5):1479-1482. http://dx.doi.org/10.1002/hep.27377.

21. Anand BS, Currie S, Dieperink E, et al. Alcohol use and treatment of hepatitis C virus: results of a national multicenter study. Gastroenterology. 2006;130(6):1607-1616. http://dx.doi.org/10.1053/j.gastro.2006.02.023.

22. Dore GJ, Ward J, Thursz M. Hepatitis C disease burden and strategies to manage the burden (Guest Editors Mark Thursz, Gregory Dore and John Ward). J Viral Hepat. 2014;21(Suppl 1):1-4. 
23. Everhart JE. Alcohol and hepatitis C: do we have a drinking problem? Gastroenterology. 2006;130(6):1912-1914. http://dx.doi.org/10.1053/j.gastro.2006.03.030.

24. Health UDo, Services H. Dietary Guidelines for Americans 2010. U.S. Department of Agriculture, 7th edition. Washington, D.C.: U.S. Government Printing Office; 2010.

25. Denniston MM, Klevens RM, McQuillan GM, Jiles RB. Awareness of infection, knowledge of hepatitis $\mathrm{C}$, and medical follow-up among individuals testing positive for hepatitis C: National Health and Nutrition Examination Survey 2001-2008. Hepatology. 2012;55(6):1652-1661. http://dx.doi.org/10.1002/hep.25556.

26. Dieperink E, Fuller B, Isenhart C, et al. Efficacy of motivational enhancement therapy on alcohol use disorders in patients with chronic hepatitis C: a randomized controlled trial. Addiction. 2014;109(11):1869-1877. http://dx.doi.org/10.1111/add.12679.

27. Force UPST. Screening and behavioral counseling interventions in primary care to reduce alcohol misuse: recommendation statement. Ann Intern Med. 2004;140(7):554-556.

28. Edlin BR, Eckhardt BJ, Shu MA, Holmberg SD, Swan T. Toward a more accurate estimate of the prevalence of hepatitis C in the United States. Hepatology. 2015;62(5):1353-1363. http://dx.doi.org/10.1002/hep.27978.

29. Tseng FC, O'Brien TR, Zhang M, et al. Seroprevalence of hepatitis C virus and hepatitis B virus among San Francisco injection drug users, 1998 to 2000. Hepatology. 2007;46(3):666-671. http://dx.doi.org/10.1002/hep.21765.

30. Edlin BR. Perspective: test and treat this silent killer. Nature. 2011;474(7350):S18-19. http://dx.doi.org/10.1038/474S18a. 
Table 1. Estimated Population Characteristics by Patterns of Alcohol Consumption among Adults aged $\geq 20$ years, NHANES $2003-2010$ $(\mathrm{n}=18,365)$

\begin{tabular}{|c|c|c|c|c|c|c|c|c|}
\hline \multirow[b]{3}{*}{ Characteristic } & \multicolumn{8}{|c|}{ Pattern of alcohol consumption } \\
\hline & \multicolumn{2}{|c|}{ Lifetime abstainers } & \multicolumn{2}{|c|}{ Former drinkers } & \multicolumn{2}{|c|}{$\begin{array}{l}\text { Non-excessive } \\
\text { current drinkers }\end{array}$} & \multicolumn{2}{|c|}{$\begin{array}{c}\text { Excessive } \\
\text { current drinkers }\end{array}$} \\
\hline & $\mathrm{n}$ & $\%(95 \% \mathrm{CI})$ & $\mathrm{n}$ & $\%(95 \% \mathrm{CI})$ & $\mathrm{n}$ & $\%(95 \% \mathrm{CI})$ & $\mathrm{n}$ & $\%(95 \% \mathrm{CI})$ \\
\hline Total & 2,568 & $11.3(10.4-12.4)$ & 3,804 & $17.2(15.9-18.6)$ & 7,285 & $41.7(40.4-43.1)$ & 4,708 & $29.8(28.3-31.2)$ \\
\hline \multicolumn{9}{|l|}{ Age group (years) ${ }^{\mathrm{a}}$} \\
\hline $20-29$ & 444 & $18.6(16.6-20.8)$ & 281 & $7.9 \quad(6.8-9.2)$ & 1,081 & $14.3(13.2-15.7)$ & 1,397 & $31.7(29.9-33.6)$ \\
\hline $30-39$ & 346 & $15.6(13.7-17.8)$ & 387 & $12.4(11.0-14.0)$ & 1,200 & $17.7(16.6-18.8)$ & 1,073 & $23.9(22.2-25.8)$ \\
\hline $40-49$ & 324 & $14.1(12.4-15.8)$ & 549 & $20.1(18.4-21.9)$ & 1,250 & $21.4(19.9-23.0)$ & 973 & $22.7(21.0-24.5)$ \\
\hline $50-59$ & 275 & $14.9(12.7-17.2)$ & 607 & $21.0(19.1-23.1)$ & 1,181 & $21.2(19.7-22.7)$ & 606 & $13.4(11.7-15.2)$ \\
\hline $60-69$ & 454 & $14.1(12.5-15.8)$ & 824 & $16.7(15.2-18.2)$ & 1,227 & $13.4(12.3-14.6)$ & 454 & $6.0 \quad(5.3-6.9)$ \\
\hline $70+$ & 725 & $22.7(20.3-25.3)$ & 1,156 & $21.9(19.8-24.2)$ & 1,346 & $12.0(10.8-13.3)$ & 205 & $2.3 \quad(1.9-2.6)$ \\
\hline \multicolumn{9}{|l|}{$\mathrm{Sex}^{\mathrm{a}}$} \\
\hline Male & 637 & $27.4(24.8-30.1)$ & 18,971 & $47.0(45.1-48.9)$ & 3,170 & $40.9(39.7-42.1)$ & 3,306 & $68.5(67.0-70.0)$ \\
\hline Female & 1,931 & $72.6(69.9-75.2)$ & 907 & $53.0(51.1-54.9)$ & 4,115 & $59.1(57.9-60.3)$ & 1,402 & $31.5(30.0-33.0)$ \\
\hline \multicolumn{9}{|l|}{ Race/ethnicity ${ }^{\mathrm{a}}$} \\
\hline Mexican- American & 579 & $9.6 \quad(7.3-12.5)$ & 715 & $7.9 \quad(5.8-10.6)$ & 1,137 & $6.2 \quad(5.2-7.4)$ & 1,048 & $10.2 \quad(8.2-12.7)$ \\
\hline Other Hispanic & 224 & $5.6 \quad(4.2-7.6)$ & 243 & $3.6 \quad(2.7-4.8)$ & 519 & $4.0 \quad(3.0-5.2)$ & 341 & $4.2 \quad(3.2-5.5)$ \\
\hline Non-Hispanic white & 1,033 & $58.4(52.2-64.4)$ & 1,927 & $70.8(65.7-75.5)$ & 3,886 & $73.0(70.0-75.9)$ & 2,480 & $74.1(70.7-77.1)$ \\
\hline Non-Hispanic black & 559 & $16.2(12.9-20.1)$ & 806 & $12.8(10.3-15.7)$ & 1,437 & $11.4(9.7-13.3)$ & 679 & $7.6 \quad(6.6-8.8)$ \\
\hline All others/multi & 173 & $10.2(8.0-12.9)$ & 113 & $4.9 \quad(3.7-6.4)$ & 306 & $5.4 \quad(4.4-6.7)$ & 160 & $(3.2-4.8)$ \\
\hline \multicolumn{9}{|l|}{ HCV status ${ }^{\mathrm{a}}$} \\
\hline HCV-RNA positive & 10 & $0.4^{\mathrm{b}} \quad(0.2-0.9)$ & 84 & $2.2 \quad(1.7-2.8)$ & 64 & $0.9 \quad(0.6-1.2)$ & 86 & $1.5 \quad(1.1-2.0)$ \\
\hline Anti-HCV negative & 2,554 & $99.6(99.1-99.8)$ & 3,690 & $97.8(97.2-98.3)$ & 7,194 & $99.1(98.8-99.4)$ & 4,590 & $98.5(98.0-98.9)$ \\
\hline \multicolumn{9}{|l|}{ Usual source of medical care ${ }^{\mathrm{a}}$} \\
\hline Yes & 2,232 & $87.5(85.6-89.2)$ & 34,133 & $90.1(88.6-91.4)$ & 6,426 & $89.1(88.0-90.1)$ & 3,587 & $78.7(76.9-80.4)$ \\
\hline No & 336 & $12.5(10.8-14.4)$ & 91 & $9.9(8.6-11.4)$ & 859 & $10.9(9.9-12.0)$ & 1,121 & $21.3(19.6-23.1)$ \\
\hline \multicolumn{9}{|l|}{ Health insurance ${ }^{\mathrm{a}}$} \\
\hline Yes & 1,975 & $80.4(77.9-82.6)$ & 3,111 & $83.6(81.5-85.4)$ & 5,917 & $84.9(83.4-86.4)$ & 3,178 & $74.6(72.8-76.4)$ \\
\hline No & 591 & $19.6(17.4-22.1)$ & 682 & $16.4(14.6-18.5)$ & 1,355 & $15.1(13.6-16.6)$ & 1,518 & $25.4(23.6-27.2)$ \\
\hline \multicolumn{9}{|l|}{ Poverty index ratio ${ }^{a}$} \\
\hline$<1.0$ (poor) & 597 & $18.0(15.7-20.4)$ & 794 & $15.4(13.5-17.4)$ & 992 & $9.7(8.6-11.0)$ & 914 & $13.3(12.0-14.8)$ \\
\hline $1.0-1.9$ (near poor) & 798 & $30.2(27.9-32.7)$ & 1,157 & $27.1(24.9-29.3)$ & 1,563 & $16.5(15.2-17.8)$ & 1,060 & $17.6(16.1-19.2)$ \\
\hline$\geq 2.0$ (not poor) & 949 & $51.8(48.3-55.3)$ & 1,583 & $57.5(55.1-60.0)$ & 4,285 & $73.8(72.0-75.5)$ & 2,438 & $69.1(66.8-71.2)$ \\
\hline \multicolumn{9}{|l|}{ Education $^{\mathrm{a}}$} \\
\hline$<$ High school & 1,000 & $27.6(24.6-30.7)$ & 1,468 & $27.2(24.6-29.8)$ & 1,519 & $13.0(12.0-14.2)$ & 1,257 & $17.1(15.5-18.9)$ \\
\hline High school graduate/GED & 607 & $25.9(23.3-28.7)$ & 973 & $29.7(27.4-32.1)$ & 1,643 & $22.4(20.9-24.0)$ & 1,185 & $24.9(23.1-26.8)$ \\
\hline$\geq$ High school graduate & 958 & $46.5(42.7-50.4)$ & 1,355 & $43.1(39.7-46.7)$ & 4,117 & $64.6(62.5-66.6)$ & 2,263 & $58.0(55.2-60.7)$ \\
\hline
\end{tabular}

achi-square $p<0.001$ for overall difference in characteristic by pattern of alcohol consumption

bestimate may be unstable because the relative SE is $>30 \%$ and should be interpreted with caution

HCV, hepatitis C virus; GED, general educational development; NHANES, National Health and Nutrition Examination Survey 
Table 2. Factors Associated With Excessive Drinking Among Current Drinkers Aged $\geq 20$ Years, NHANES 2003-2010 $(n=11,993)$

\section{Prevalence ratios for excessive current drinking}

Simple logistic model Final multivariate model

Prevalence ratio $(95 \% \mathrm{CI}) \quad$ Adjusted prevalence ratio $(95 \% \mathrm{CI})$

\begin{tabular}{|c|c|c|}
\hline \multicolumn{3}{|l|}{ Age group } \\
\hline $20-39$ & $4.7(4.0-5.5)^{* * *}$ & $4.6(3.9-5.4)^{* * * *}$ \\
\hline $40-49$ & $3.7(3.1-4.3)^{* * * *}$ & $3.6(3.1-4.3)^{* * * *}$ \\
\hline $50-59$ & $2.6(2.1-3.3)^{* * * *}$ & $2.6(2.1-3.2)^{* * * *}$ \\
\hline $60-69$ & $2.1(1.7-2.5)^{* * * *}$ & $2.1(1.7-2.5)^{* * * *}$ \\
\hline $70+$ & ref & ref \\
\hline \multicolumn{3}{|l|}{ Sex } \\
\hline Male & $2.0(1.9-2.1)^{* * * *}$ & $1.9(1.8-2.0)^{* * * *}$ \\
\hline Female & ref & ref \\
\hline \multicolumn{3}{|l|}{ Race/ethnicity } \\
\hline Non-Hispanic black & $0.8(0.7-0.9)^{* * *}$ & $0.7(0.6-0.8)^{* * * *}$ \\
\hline All others & ref & ref \\
\hline \multicolumn{3}{|l|}{ HCV status } \\
\hline HCV-RNA+ & $1.3(1.1-1.6)^{*}$ & $1.3(1.1-1.6)^{*}$ \\
\hline Anti-HCV negative & ref & ref \\
\hline \multicolumn{3}{|l|}{$\begin{array}{l}\text { Usual source of medical } \\
\text { care }\end{array}$} \\
\hline Yes & ref & ref \\
\hline No & $1.5(1.4-1.6)^{* * * *}$ & $1.1(1.02-1.2)^{*}$ \\
\hline \multicolumn{3}{|l|}{ Health insurance } \\
\hline Yes & ref & \\
\hline No & $1.4(1.3-1.5)^{* * *}$ & NS \\
\hline \multicolumn{3}{|l|}{ Education } \\
\hline$<$ HS graduate & $1.2(1.1-1.3)^{* * *}$ & $1.2(1.1-1.3)^{* * * *}$ \\
\hline HS graduate/GED & $1.1(1.04-1.2)^{* *}$ & $1.1(1.05-1.2)^{* * *}$ \\
\hline$>$ HS graduate & ref & ref \\
\hline \multicolumn{3}{|l|}{ Poverty index ratio } \\
\hline$<1.0$ & $1.2(1.1-1.3)^{* * * *}$ & \\
\hline $1.0-1.9$ & $1.1(1.01-1.2)^{*}$ & \\
\hline$\geq 2.0$ & ref & NS \\
\hline
\end{tabular}


Table 3. Estimated Characteristics of Former and Current Drinkers Aged $\geq 20$ years, NHANES 2003$2010(\mathrm{n}=15,797)$

\begin{tabular}{|c|c|c|c|c|}
\hline \multirow[b]{2}{*}{ Characteristic } & \multicolumn{2}{|c|}{ Former drinkers } & \multicolumn{2}{|c|}{ Current drinkers } \\
\hline & $\mathrm{n}$ & $\%(95 \% \mathrm{CI})$ & $\mathrm{n}$ & $\%(95 \% \mathrm{CI})$ \\
\hline \multicolumn{5}{|l|}{ Age group (years) ${ }^{* * *}$} \\
\hline $20-29$ & 281 & $7.9 \quad(6.8-9.2)$ & 2,478 & $21.6(20.4-22.9)$ \\
\hline $30-39$ & 387 & $12.4(11.0-14.0)$ & 2,273 & $20.3(19.2-21.4)$ \\
\hline $40-49$ & 549 & $20.1(18.4-21.9)$ & 2,223 & $22.0(20.9-23.1)$ \\
\hline $50-59$ & 607 & $21.0(19.1-23.1)$ & 1,787 & $17.9(16.9-19.0)$ \\
\hline $60-69$ & 824 & $16.7(15.2-18.2)$ & 1,681 & $10.3(9.5-11.2)$ \\
\hline $70+$ & 1,156 & $21.9(19.8-24.2)$ & 1,551 & $7.9 \quad(7.2-8.8)$ \\
\hline \multicolumn{5}{|l|}{$\operatorname{Sex}^{* * *}$} \\
\hline Male & 1,897 & $47.0(45.1-48.9)$ & 6,476 & $52.4(51.6-53.2)$ \\
\hline Female & 1,907 & $53.0(51.1-54.9)$ & 5,517 & $47.6(46.8-48.4)$ \\
\hline \multicolumn{5}{|l|}{ Race/ethnicity $^{*}$} \\
\hline Mexican- American & 715 & $7.9 \quad(5.8-10.6)$ & 2,185 & $(6.4-9.5)$ \\
\hline Other Hispanic & 243 & $3.6 \quad(2.7-4.8)$ & 860 & $4.1 \quad(3.2-5.2)$ \\
\hline Non-Hispanic white & 1,927 & $70.8(65.7-75.5)$ & 6,366 & $73.5(70.5-76.2)$ \\
\hline Non-Hispanic black & 806 & $12.8(10.3-15.7)$ & 2,116 & $9.8(8.5-11.3)$ \\
\hline All others/multi & 113 & $4.9 \quad(3.7-6.4)$ & 466 & $4.8 \quad(4.1-5.7)$ \\
\hline \multicolumn{5}{|l|}{ HCV status ${ }^{* * *}$} \\
\hline HCV-RNA positive & 84 & $2.2 \quad(1.7-2.8)$ & 150 & $1.1 \quad(0.9-1.4)$ \\
\hline Anti-HCV negative & 3,690 & 97.8 (97.2-98.3) & 11,784 & $98.9(98.6-99.1)$ \\
\hline \multicolumn{5}{|l|}{$\begin{array}{l}\text { Usual source of medical } \\
\text { care }\end{array}$} \\
\hline Yes & 3,413 & $90.1(88.6-91.4)$ & 10,013 & $84.8(83.7-85.8)$ \\
\hline No & 391 & $9.9(8.6-11.4)$ & 1,980 & $15.2(14.2-16.3)$ \\
\hline \multicolumn{5}{|l|}{ Health insurance $^{* *}$} \\
\hline Yes & 3,111 & $83.6(81.5-85.4)$ & 9,095 & $80.7(79.3-82.0)$ \\
\hline No & 682 & $16.4(14.6-18.5)$ & 2,873 & $19.3(18.0-20.7)$ \\
\hline \multicolumn{5}{|l|}{ Poverty index ratio $^{* * *}$} \\
\hline$<1.0$ (poor) & 794 & $15.4(13.5-17.4)$ & 1,906 & $11.2(10.2-12.3)$ \\
\hline $1.0-1.9$ (near poor) & 1,157 & $27.1(24.9-29.3)$ & 2,623 & $17.0(15.9-18.0)$ \\
\hline$\geq 2.0$ (not poor) & 1,583 & $57.5(55.1-60.0)$ & 6,723 & $71.8(70.2-73.4)$ \\
\hline \multicolumn{5}{|l|}{ Education $^{* * *}$} \\
\hline$<$ High school (HS) & 1,468 & $27.2(24.6-29.8)$ & 2,776 & $14.7(13.6-15.9)$ \\
\hline HS graduate/GED & 973 & $29.7(27.4-32.1)$ & 2,828 & $23.5(22.3-24.6)$ \\
\hline$\geq \mathrm{HS}$ graduate & 1,355 & $43.1(39.7-46.7)$ & 6,380 & $61.8(59.9-63.7)$ \\
\hline
\end{tabular}

Note: Boldface indicates statistical significance chi-square for overall difference in characteristic by level of alcohol consumption * $p<0.05 ;{ }^{* *} p<0.01 ;{ }^{* * *} p<0.001$

$\mathrm{HCV}$, hepatitis C virus; GED, general educational development; NHANES, National Health and Nutrition Examination Survey 
Table 4. Factors Associated With Former vs. Current Drinking Among Adults Aged $\geq 20$ Years, NHANES 2003-2010 $(n=15,797)$

\begin{tabular}{|c|c|c|}
\hline & \multicolumn{2}{|c|}{ Prevalence ratios for being a former vs. a current drinker } \\
\hline & $\begin{array}{c}\text { Simple logistic model } \\
\text { Prevalence ratio }(95 \% \mathrm{CI})\end{array}$ & $\begin{array}{c}\text { Final multivariate model } \\
\text { Adjusted prevalence ratio }(95 \% \mathrm{CI})\end{array}$ \\
\hline $\begin{array}{c}\text { Age group } \\
20-39 \\
40-49 \\
50-59 \\
60-69 \\
70+\end{array}$ & $\begin{array}{l}0.26(0.23-0.30)^{* * * *} \\
0.45(0.40-0.51)^{* * * *} \\
0.55(0.48-0.63)^{* * *} \\
0.70(0.62-0.79)^{* * *} \\
\text { ref }\end{array}$ & $\begin{array}{l}0.30(0.26-0.34)^{* * * *} \\
0.51(0.45-0.58)^{* * * *} \\
0.64(0.55-0.73)^{* * * *} \\
0.75(0.66-0.85)^{* * *} \\
\text { ref }\end{array}$ \\
\hline $\begin{array}{l}\text { Sex } \\
\quad \text { Male } \\
\text { Female } \\
\end{array}$ & $\begin{array}{l}0.8(0.7-0.9)^{* * *} \\
\text { ref }\end{array}$ & $\begin{array}{l}\mathbf{0 . 9}(\mathbf{0 . 8}-\mathbf{0 . 9})^{* * * *} \\
\text { ref }\end{array}$ \\
\hline $\begin{array}{l}\text { Race/ethnicity } \\
\text { Non-Hispanic } \\
\text { black } \\
\text { All others }\end{array}$ & $\begin{array}{l}1.3(1.1-1.4)^{* * *} \\
\text { ref }\end{array}$ & $\begin{array}{l}1.2(1.01-1.3)^{*} \\
\text { ref }\end{array}$ \\
\hline $\begin{array}{l}\text { HCV status } \\
\text { HCV-RNA+ } \\
\text { Anti-HCV } \\
\text { negative }\end{array}$ & $\begin{array}{l}1.7(1.4-2.0)^{* * *} \\
\text { ref }\end{array}$ & $\begin{array}{l}1.3(1.1-1.6)^{*} \\
\text { ref }\end{array}$ \\
\hline $\begin{array}{l}\text { Usual source of } \\
\text { medical care } \\
\text { Yes } \\
\text { No }\end{array}$ & $\begin{array}{l}\text { ref } \\
0.7(0.6-0.8)^{* * * *}\end{array}$ & $\begin{array}{l}\text { ref } \\
0.8(0.7-0.9)^{* *}\end{array}$ \\
\hline $\begin{array}{l}\text { Health insurance } \\
\text { Yes } \\
\text { No }\end{array}$ & $\begin{array}{l}\text { ref } \\
0.8(0.7-0.9)^{* *}\end{array}$ & NS \\
\hline $\begin{array}{l}\text { Education } \\
<\text { HS graduate } \\
\text { HS graduate/GED } \\
>\text { HS graduate }\end{array}$ & $\begin{array}{l}2.1(1.9-2.4)^{* * *} \\
1.6(1.4-1.8)^{* * *} \\
\text { ref }\end{array}$ & $\begin{array}{l}1.7(1.5-1.9)^{* * *} \\
1.4(1.3-1.6)^{* * *} \\
\text { ref }\end{array}$ \\
\hline $\begin{array}{l}\text { Poverty index ratio } \\
\quad<1.0 \\
1.0-1.9 \\
\geq 2.0\end{array}$ & $\begin{array}{l}1.5(1.4-1.7)^{* * *} \\
1.7(1.6-1.9)^{* * *} \\
\text { ref }\end{array}$ & $\begin{array}{l}1.5(1.3-1.7)^{* * *} \\
1.5(1.3-1.6)^{* * *} \\
\text { ref }\end{array}$ \\
\hline
\end{tabular}

Note: Boldface indicates statistical significance ${ }^{*} p<0.05 ;{ }^{* *} p<0.01 ;{ }^{* * * *} p<0.001$ for logistic model coefficients. NS, not significant in multivariate models; not included in final model; HCV, hepatitis C virus; HS, high school; GED, general educational development; NHANES, National Health and Nutrition Examination Survey 